\title{
Plant Factory Engineering Strategy of Japanese Manufacturer and Agri-Business Innovation
}

\author{
Suguru Yanata1, Takao Nomakuchi ${ }^{1}$, Kaori Ishibashi² \\ ${ }^{1}$ Faculty of Economics, Wakayama University, Wakayama City, Japan \\ ${ }^{2}$ Wakayama Shin-ai Junior and Senior High School, Wakayama City, Japan \\ Email: yanata@eco.wakayama-u.ac.jp
}

Received February 2015

\section{Abstract}

These days, some manufacturing enterprises which are forced to diversify management enter AgriBusiness and plant factory business, make an Innovation utilizing high research and development ability and enough capital. As Agri-Business Innovation in Japan, this study examinedNK Agri, a subsidiary company of Noritsu Koki, which is a motion picture producer and machinery maker, based on Industrial Cluster Theory and Diamond Model by Michael E. Porter. The important points to enter Agri-Business of manufacturing enterpriseswere summed up as below. 1) New coming manufacture enterprises can form Industrial Cluster with farmhouse and foods makers, and enhance productivity and competitiveness. 2) New coming manufacture enterprises can enhance productive efficiency by collaborating with orthodox farmhouses as important partners. 3) Research institutions such as universities and local government should support for forming and development of Agri Industrial Cluster by manufacture enterprises. Agri Industrial Cluster by manufacture enterprises can improve local economy, so local government should prepare for the system to expand support as a policy.

\section{Keywords}

Agriculture, Plant Factory, Manufacturing Enterprise, Innovation, Branding, Strategy, Industrial Cluster, Agri-Business

\section{Introduction}

Globalization of economy and change of industrial structure force Japanese manufacturing enterprises (makers) to change business models and to diversify. Such makers enter agriculture which are different from their main business "Manufacturing".

When manufacturers as players of secondary industry enter agriculture, sometimes they develop and produce agricultural implements by utilizing manufacturing enterprise experiences, and sometimes, they start plant cultivation such as vegetables and garden plants and enter agriculture as primary industry. In the latter case, they 
often enter agriculture to manage plant factories by utilizing agricultural biotechnology, Information and Communication Technology (ICT), or they develop high-value added breeds, produce and sell on a large scale with orthodox farmhouses.

Manufacturers entering agriculture and in collaboration with orthodox farmhouses are seen these days. Taking a farm economic view of things, this can be new business "Agri-Business" which collaborates with different industries, engineering technology and orthodox agriculture. Besides, this can be an innovation in Agri-Business, because new value is added. Such innovation may contribute to local industrial network and Industrial Cluster formation, which may contribute to improvement of regional economy too.

In this study, a Japanese Manufacture which enters agricultural business, is examined, and makes an innovation collaborating with surrounding orthodox farmhouses. The Japanese Manufacture is NK Agri, which is a subsidiary company of Noritsu Koki, which is a motion picture producer and machinery maker.

\section{Plant Factory and Business}

Plant factory defines as an advanced technology combined orthodox agriculture equipment, which controls strictly natural conditions such as halation, temperature and water quantities, and chemical substances such as agricultural chemicals and fertilizers by ICT [1] [2]. Plant factory business is a high end technology industry requiring advanced agricultural technology and ICT. It can be seen this from that the company's employee comments "Plant factory is similar to manufacturing not agriculture". Plant factories can avoid risks such as "mismatched supply and demand" and "quality controls”, which orthodox agriculture can't avoid. Also, they also can cultivate high-value added plants such as organic vegetables, functional vegetables, and plants for medicine.

Such plant factories are wide spread in Holland and Israel. East Asian countries such as China and Korea are interested in it these days. In Japan, people are interested in stable supply of foods, and safety of foods, after a huge earth quake and a nuclear power generation trouble in March 2011. It is expected that the plant factories, which can control cultivation environment strictly will attract people more [2].

Of course, plant factory has demerits too. For example, initial investment and running cost (especially personnel expenses, fuel and light expenses) is expensive [2]. In other words, plant factory business is hard to get a profit now. Therefore, only companies which have capital strength and can afford initial investment, running cost until getting profit can entry Agri-Business utilizing plant factory. That's why it is important to improve awareness based on branding strategy to get enough profit for business continuity, also it is important to set high pricing, and to find a market to sell out. To sum up, when manufacturers enter this business, it is a difficult task branding in a different field, and finding a market.

However, manufacturers which enter Agri-Business have difficulty branding in the agricultural field, and finding a market. In market strategy, It should be referred to Industrial Cluster Theory (Strategy), strengthening network among local companies, by Michael E. Porter. This theory, which collaborates surroundings, which supplies the shortage, which earns profits with synergy effect, which promotes new innovation and improves competitiveness, to this theory should be applied.

Porter defined Industrial Cluster as "A cluster is a geographical proximate group of interconnected companies and associated institutions in a particular field, linked by commonalities and externalities” [3]. To relate to this, he said that it is important to form high productive cluster with industry, academia and government network. To support this theory, Diamond Model (Figure 1) by Porter is referred to [4]. If Industrial Cluster is formed in an area, and conditions shown in Diamond Model are satisfied, productivity will improve, innovation will be promoted, and entrepreneurship will activate and improve competitiveness. However, plant factory business is a new industry, it seems that the company network is weak. That's why it will take time to form Industrial Cluster. Therefore, priority is in collaboration between academia and government. Especially, a research institution such as university is required to play important roles as a mediator. After that, if the business grows and becomes stable, the network will include government and it contributes to local economy as a result. In this sense, financial support from government is reasonable. Besides, it is also important to collaborate between academia and government from the beginning to develop local industry.

Thinking about Cluster of plant factory business, when collaborating with no capital, it is important to choose experienced farmhouses, especially if on a large scale for a long period of time, although it may not include industry. To share intellectual property (know-hows, experiences), and to divide productive processes are options 


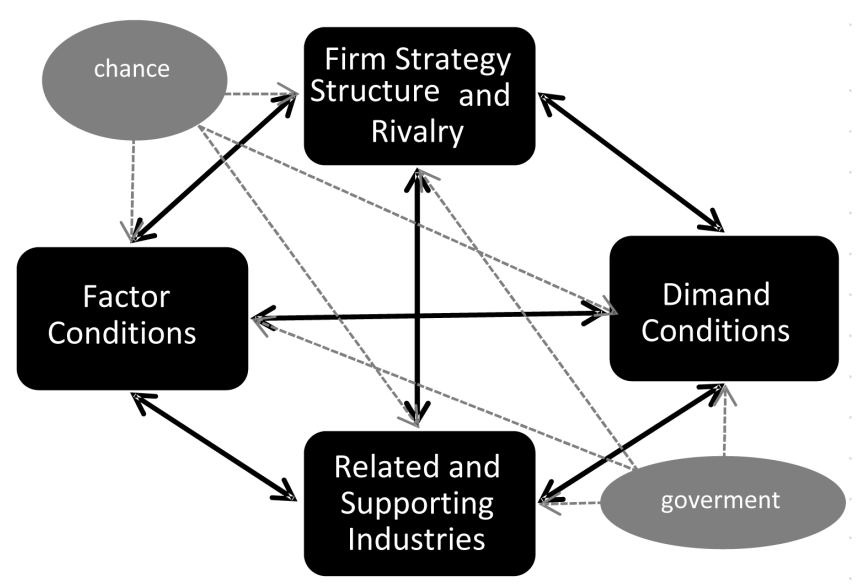

Figure 1. Porter's diamond model. Source: [4].

with high priority. Specifically, it means to utilize agricultural cloud, and consign high-value added breeds to surrounding orthodox farmhouses. If such collaborations are established, new local bland can be born, related companies' profit can increase by that brand becoming famous. Furthermore, positive economic effects will influence distributers and retailers. In addition, it is important to utilize existing social network which has been built as manufactures. This is explained by Diamond Model too.

In any case, forming agricultural Industrial Cluster by manufactures is innovation. Also, if essential factors in Diamond Model are established, it can keep advantage comparing to the same kinds of Cluster as long as it grows. If any new born venture companies can survive too, which contributes to improve of local economy.

To sum up, manufacturing enterprises entering to plant factory business and agri-business can success referring to Industrial Cluster Theory and Diamond Model, which is preferable.

\section{Case Study}

It is NK Agri, which can cause innovation, and that forms Industrial Cluster combined agriculture and manufacture. NK Agri is relatively new company of a subsidiary company of Noritsu Koki Figure 2, which is listed on the first section of the Tokyo Stock Exchange manufacture enterprise.

Noritsu Koki was established in 1951, in Wakayama prefecture near to Osaka prefecture. It grows as a maker of picture films and machinery. It is the global company which has 13 relative companies in Japan, and branches and relative companies in more than 10 abroad countries. However, after digital cameras became popular in 2000, films and analog camera relative machinery market, which are the main market of this company, drastically shrunk. Such market situation forced this company to change business model, as a result, this company entered new fields and diversified. This company called this diversification " $2{ }^{\text {nd }}$ establishment". This company adopted holding company system, and Noritsu Koki became on top of that system. This company established 4 subsidiary companies (NK Works, NK Agri, NK Relations, NK Medico,). Each subsidiary took in charge of Environment, Food, Business Development, and Preventive Medicine. NK Agri was established in 2009, and took in charge of food business. This company was run by 70 full time and part time workers in January, 2015. This company has 3 business contents, "plant factory" "producing area collaboration" "research and development”, and main business content is cultivating vegetables in Japanese largest scale plant factories. Besides, this company develops functional vegetables and produces high-value added breeds with surrounding orthodox farmhouses.

In regard to plant factory business in NK Agri, plant factory equipment locates in Noritsu Koki, in Wakayama City, Wakayama Prefecture. Site area is 1 ha, the largest scale in Japan. This company cultivates hydroponics with sun light, air-conditioning and water volume are controlled by ICT strictly. This company cultivates leaf vegetables like lettuce with little agricultural chemicals. Person in charge says that they can produce 8 times lettuce a year. They bland cultivated vegetables as in-house products, and name AQUALEAF series, "Syakisyaki Frill”, "Yawaraka Ruby”, "Irodori Lettuce Mix”, “Amedama Lettuce”, AQUA GARDEN series, "Salad Spinach", "Salad Mizuna". About AQUA GARDEN series is cultivated in collaborated orthodox farmhouses instructed by NK Agri. 


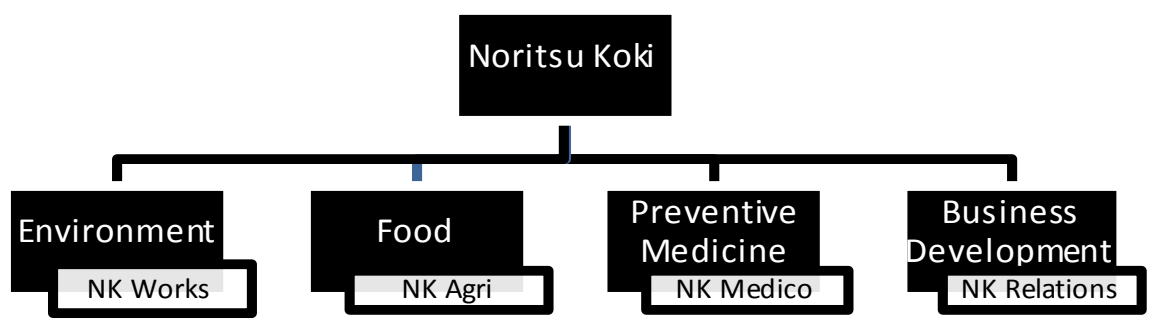

Figure 2. Noritsu Koki.

In regard to the market, vegetables cultivated in plant factory are sold in 34 stores in Japan, such as Wakayama prefecture, the local area, Kanto, Tokai, Kinki, Naka-Chugoku areas. Now, these vegetables are not sold abroad, but if this company wants, these vegetables can be sold in markets abroad in the near future.

As other business contents, NK Agri, has "producing area collaboration", "research and development". These two business contents are done at the same time. This company aims to create demands of new products and expand consumers by collaborating farmhouses who try to new agriculture and enabling technology which NK Agri has. In other words, NK Agri takes in charge of breeding innovation which farmhouses can't do, and farmhouses take in charge of mass cultivation which NK Agri, can't do. As a result, both create collaborating relation to get new demand and new consumers. For example, when NK Agri taught orange and strawberry farmhouses to revise kinds of fertilizers, farmhouses achieved nutritional value increasing and freshness keeping longer. They also achieved to set apart from other ones and price stability by branding strategy.

This is how the basement of Industrial Cluster whose center is NK Agri, is forming now, and farmhouses which is not included as players of Industrial Cluster ordinary. On this point, it can be said that an innovative model is forming.

Hereafter, research institutions such as universities and local government should support this company more. In the view of local economic policy, it is important to grow this company's business, because if Industrial Cluster forms and expands, relative companies will have more opportunities to increase profits, and local industries especially agriculture, the main industry in Wakayama prefecture will improve. In the population construction, Wakayama prefecture has a certain agricultural workers, so giving the business chance to agricultural workers will be a support of local improvement. If this company's business succeeds, the same kind of Industrial Cluster may be forming in another area. Even if such competitive local Industrial Cluster causes, this company has first mover's advantage, so doesn't get critical damage. Conversely, such competitive relationship is preferable not only for local economy but also national economy. In this point, government and academia should support this business.

Now, NK Agri forms a consortium with Kyoto Prefectural University, The University of Tokyo, Nisshin Seifun, researches and develops functional foods (vegetables). Also this company joins "The Subsidy for the Advanced Industrial Technology Research and Development (from Wakayama Prefectural Government)" supported by Wakayama prefecture, researches and develops to increase certain nutrition in leaf vegetables such as Lettuce. The result will be release later, it seems to go well in engineering view.

\section{Conclusions}

These days, some manufacturing enterprises which are forced to diversify management enter Agri-Business and plant factory business utilizing high research and development ability and enough capital. It is shown that it is important for such manufacturing enterprises to have Industrial Cluster Strategy and Branding Strategy. As the case study, NK Agri succeeds enough. The important points to enter Agri-Business are summed up as below.

- New coming manufacture enterprises can form Industrial Cluster with farmhouses and foods makers, and enhance productivity and competitiveness.

- New coming manufacture enterprises can enhance productive efficiency by collaborating with orthodox farmhouses as important partners.

- Research institutions such as universities and local government should support for forming and development of Agri Industrial Cluster by manufacture enterprises.

- Agri Industrial Cluster by manufacture enterprises can activate local economy, so local government should prepare for the system to expand support as a policy. 
NK Agri is focused on in this study, so universal ideas can't be suggested to be common with the theme in some points. That's why case study numbers will be increased, and the universal theory will be found.

\section{Acknowledgements}

The information sources of this study are public and provided by NK Agri,. Taking advantage of this opportunity, we would like to express our appreciation.

And this work partly was supported by the Institute of Economic Research, Faculty of Economics, Wakayama University.

\section{References}

[1] Yamamoto, H. (2014) Shokubutsukoujou. Nourintoukei Shuppann.

[2] Yanata, S. and Takata, K. (2014) Plant Factory: The Possible Measures to Revitalize the Wakayama's Economy, Regional Studies Series No. 43 (Revised Edition). Institute of Economic Research, Faculty of Economics, Wakayama University, 1-22.

[3] Porter, M.E. (1998) On Competition. Harvard Business School Press.

[4] Porter, M.E. (1990) The Competitive Advantage of Nations. Free Press. 